\title{
Gender equality: legislative issues of the Russian Federation in socio-political discourse
}

\author{
Svetlana Skorniakova ${ }^{1}$, Veronika Leontyeva ${ }^{1}$, Dmitrii Popov ${ }^{1,}{ }^{*}$, Veronika Fokina ${ }^{1}$, and \\ Anna Safonova ${ }^{1}$ \\ ${ }^{1}$ Peter the Great St. Petersburg Polytechnic University, 195251 St.-Petersburg, Russia
}

\begin{abstract}
The article provides a comparative analysis of the national strategy to improve the status of women in the Russian Federation and alternative legislation on gender equality, as well as the heated debate that has developed in the media on the implementation of equal rights and equal opportunities for women and men. The clash of opinions is considered from the point of view of correspondence of the discussion of the issue of gender equality to the specific actions of the actors involved in it. Shown are the changes in Russian gender policy, often quite formal, and, as a result, the deterioration of international indicators of Russia's place in the ranking of gender equality. Various approaches to the definition of the term "gender" in the public are shown.
\end{abstract}

\section{Introduction}

Socio-political dialogue on gender issues is especially characteristic for societies that have embarked on the path of modernization. The data of studies and surveys presented in the scientific community indicate the presence of serious, but partially hidden, contradictions in Russian society [1].

Researchers of gender proceed from the fact that ideas about gender are different throughout the world, but all countries of the world in one form or another are characterized by sharp discussions on issues of both legislative and value understanding of the problems. Modern intersectional studies consider the concept of gender not as a self-sufficient category, but in combination with ethnicity, race, age, social status, sexual orientation, which allows us to reconstruct and detect hidden forms of inequality at the intersection of these signs $[2,3]$. Russian researchers are following the trend for gender studies in the field of interaction between the state, society and business [4].

The Russian Federation seems to be an interesting example when, on the whole, modernist ideas on gender issues in society are faced with a conservative interpretation in the field of perception of social groups and elites. It can be noted that the politicization of problem of the place and role of gender in social issues is not only a matter of public dialogue and scientific research. The concept of women's political participation implies not

* Corresponding author: klacik_p2@list.ru 
only social, but also legislative activity. And the opportunities and desire of women to use political organizations and processes is connected with making their political preferences visible and, ultimately, influencing others [5]. According to the authors, one should consider how the discussion of gender legislation in modern Russia takes place and which interest groups are represented at this stage in this discourse. The authors proceed from the following provision that in order to enhance the political participation of women, support from social and economic structures, the absence of discrimination of women at the level of laws, and the elimination of negative stereotypes regarding women in the education system and the media are necessary. And in this regard, the creation of specialized strategies for women and their effective implementation is a key stage in the development of modern Russian society.

\section{Materials and Methods}

The research methodology is based on the analysis of documents and content analysis of key speeches by representatives of groups involved in the process of making and / or discussing decisions on gender legislation, as well as the results of a sociological survey on the subject of the study.

In the modern world, discrimination based on gender is considered unacceptable, but in Russia the destruction of gender stereotypes runs into a conservative reaction both from state and public institutions.

In order to identify the features of modern gender relations, to study methods for the formation of the concepts of "masculinity", "femininity" and "gender", from 03.02.2020 to 12.02.2020, a sociological survey was conducted using the online questionnaire on the topic "Socio-political discourse on gender policy issues", which was attended by 120 respondents. The age "core" of respondents was 18-39 years old (over 80\%).

The study revealed that only half of the participants $-51.1 \%$ understand the fundamental differences between the concepts of "sex" and "gender". $25.4 \%$ answered that there are no differences between these terms, and $19.4 \%$ found it difficult to answer.

Only $16.1 \%$ of respondents expressed constant interest in gender and feminist issues in the Russian Federation, more than half $-51.7 \%$ said that they were interested in these problems only from time to time, while for $32.2 \%$ of the survey participants this topic was not at all seems relevant.

As noted above, in Russia the problems of gender inequality require special attention and analysis both from the side of public administration institutions and from the structures of civil-public control. Today, the struggle for gender equality is becoming a global problem. One of the striking global examples on this topic is the HeForShe social project, which urges men around the world to fight for women's rights.

The study also found that more than half of the respondents "unconditionally support" (16.1\%) or "rather support" $(43.2 \%)$ feminist movements, while "certainly do not support" and "rather do not support" $6.8 \%$ and $15.3 \%$, respectively, which demonstrates a stable trend and correlates with the All-Russian Center for the Study of Public Opinion survey conducted in March 2019.

It is important to note that in Russian society, feminism is often understood and perceived not as a struggle for equality, but as a kind of radical movement of women against men, which is fundamentally wrong.

On the issue of gender stratification - "Do you agree that in the modern world there is an unequal distribution of wealth, power and privileges between men and women?" $66.9 \%$ of respondents gave an affirmative answer, $25.4 \%$ of respondents - a negative one and $7.6 \%$ found it difficult to answer. 
The survey also showed that for the vast majority of respondents $(48.3 \%)$ the equality of the rights of men and women in modern Russia seems to be the most realistic scenario only in certain areas. The possibility of equality in all spheres was noted by $33.1 \%, 14.4 \%$ of respondents declared the impossibility of equal rights as a whole and $4.2 \%$ found it difficult to answer.

During the survey, participants were also asked to determine what type of gender attitudes the Russian Federation belongs to. The answers were distributed as follows (in order of importance): $44.1 \%$ - the patriarchal type of gender attitudes prevails, a significant role is played by feminist attitudes; $32.2 \%$ - the patriarchal type of gender attitudes of consciousness prevails; $10.2 \%$ - both types of gender attitudes of consciousness have an equal effect; $6.8 \%$ - the feminist type of gender attitudes of consciousness prevails; $6.7 \%$ the feminist type of gender attitudes prevails, a significant role is played by patriarchal attitudes.

For more than $70 \%$ of respondents, it is obvious that the difference in the social status of women and men, the inequality of their rights can be explained by social reasons. Nevertheless, $28 \%$ of respondents believe that the biological factor is the basis of inequality. However, to the question "Do you agree with the statement that acceptable and unacceptable social roles for men and women are set by the society itself, its culture, norms and values", $89 \%$ of respondents answered in the affirmative.

Of particular interest were the answers to the question regarding awareness of official gender policy documents. So, 54.2\% know about the draft law "On Prevention of Domestic Violence in the Russian Federation" (RF), 37.5\% - about the UN Convention on the Elimination of All Forms of Discrimination against Women (UN), 11.7\% - about Draft Federal Law No. 284965-3 "On State Guarantees of Equal Rights and Freedoms of Men and Women and Equal Opportunities for Their Implementation" (RF), $2.5 \%$ on the National Strategy for Women's Interests for 2017 - 2022 (RF). It is significant that $34.2 \%$ were not familiar with any of the above mentioned documents.

Today, the issues of enhancing the participation of Russian women in politics are gaining particular relevance. All citizens can and should equally participate in the political process so that their views are heard and transformed into specific political actions or decisions. The systematic neglect of group interests leads to a distortion of the political representation of women, in which the interests of certain privileged groups begin to dominate in socio-political discourse. The statement that "in order to enhance the political participation of women in Russian politics, support from social and economic structures, the absence of discrimination of women at the level of laws, and the elimination of negative stereotypes regarding women in the education system and the media are necessary", $65.3 \%$ of respondents agreed while $13.6 \%$ found it difficult to answer, and $21.2 \%$ did not agree with this definition.

\section{Results}

On March 8, 2017, the Government of the Russian Federation approved the National Strategy of Actions for Women for 2017 - 2022 (hereinafter - the Strategy). The document emphasized that "The strategy is based on the fact that women's rights are an integral part of general human rights. Creating conditions for the full and equal participation of women in the political, economic, social, and cultural spheres of society is a priority for the state policy of the Russian Federation. "It was also noted there that one of the obstacles to the realization of the principle of equality "is the prevailing social understanding of the woman's social role that negatively affects the self-realization and development of their individuality, impedes their free choice of profession and lifestyle and creates barriers to achieving actual gender equality both in socio-political and in socio-economic life ". It is 
significant that the term "gender" is never used in this document. And there are quite good reasons for this.

The adoption of the Strategy was preceded by a very heated discussion in Russian society on the problems of the law on gender equality. The Russian Federation, as a state party to the UN Convention on the Elimination of All Forms of Discrimination against Women, has undertaken to fulfill the obligations of the Convention, which require a national mechanism for gender equality in the country.

The national mechanism for gender equality is a special system of political governance institutes and practical measures of the state, aimed at introducing a gender approach in all areas of politics and at solving gender problems in all areas of public and social life. For the functioning of this mechanism, it was necessary to create a legal framework. Therefore, in 2003, a draft federal law No. 284965-3 "On State Guarantees of Equal Rights and Freedoms of Men and Women, and Equal Opportunities for Their Implementation" was submitted to the State Duma. However, the Russian government gave a negative conclusion and shelved the bill. Nevertheless, this was the first attempt to introduce a new concept of "gender" into Russian legislation and public consciousness.

The next attempt to submit the draft law on gender equality for second reading was made by Elena Mizulina in 2012, a deputy of the State Duma from "Fair Russia" party. In this document, real mechanisms have been proposed to prevent gender discrimination in "hiring, promotion and salary", creating "conditions for combining professional and family responsibilities". In the political sphere, it was also proposed to achieve gender balance and ensure equal representation of women and men at different levels of political power. To maintain this balance, the law provided for the introduction of gender quotas, as well as the position of the Commissioner for Gender Equality. Thus, the law created the conditions and proposed a real mechanism (in the form of new departments and the Ombudsman) that would allow monitoring the observance of the principle of gender equality in a particular area, considering a specific case of discrimination within its individual context [6]. This legislative initiative faced considerable resistance from the nationalist, Orthodox, and parental communities and caused fierce criticism from conservative circles, for whom the word "gender" itself was associated with something very negative.

A sharp condemnation of legislation on gender equality was made by the Russian Orthodox Church. Priest Maxim Kaskun said that "today's appearance of feminism no longer looks like a struggle for the rights of women, and looks like man-hating, sometimes turning into outright hooliganism, sacrilege and outrageous. The Orthodox Church will never approve of such acts, since they contradict the Christian worldview.

They are echoed by national-patriotic organizations. Leader of the St. Petersburg branch of the People's Cathedral movement A. Artyukh said: "The adoption of this law involves not only equal rights for women, but also gives to sexual perverts the right to position Sodom sin as the norm. Today they're running around with posters. "My gender is my choice. In fact, gender ideology is an attack of globalists on both men and women, the Church, the traditional family and children".

Actively opposed the bill, parental public organizations. The Association of Parents' Committees and Communities "ARKS" appealed to the initiator of the bill, the deputy of the State Duma E.B. Mizulina: "in fact, the bill is aimed not so much at respecting the equality of rights of men and women, but, based on a vicious feminist ideology, aimed at the actual blurring of the boundaries between male and female sexes, bringing them into a unified state of gender."

The inter-regional social movement "Family, Love, Fatherland" stated that "the bill creates a legal framework for the legalization of perversions, unhindered access for sodomites and lesbians to our children, perverts traditional family values, traditional moral standards, moral standards, destroys family foundations". At the request of this 
organization, Doctor of Law, Professor of the Russian Academy of National Economy and Public Administration under the President of the Russian Federation, Professor I.V. Ponkin made an official conclusion (Conclusion on the draft federal law No. 284965-3 (2012)) "the most significant drawback of the Bill under consideration, which determines the negative, harmful potential, is the replacement of the extremely semantically clear concept of "sex", with the ideologically labeled concept of "gender". This desire does not find any rational explanation, except as an explanation by the interests of promoting the achievement of the goals of foreign LGBT organizations for the violent reform of the family institution in Russia”.

There were voices in support of the bill. A number of women's organizations initiated the collection of signatures under the Open Letter to the President of the Russian Federation, the Government of the Russian Federation in support of the constitutional principles of equal rights and opportunities for women and men in the Russian Federation (An open letter in support of the constitutional principle of equal rights and opportunities for women and men in the Russian Federation (2012)). The appeal noted that "in recent years in Russia there has been a rollback from compliance with the principle of equal rights for women and men, which is guaranteed by the Constitution of our country and a number of international obligations. Traditional stereotypes "women have no place in politics and governance" are being re-cultivated. And it is especially important to emphasize that a number of previously existing state structures responsible for the development of equal rights for men and women have been eliminated - the Commission on Women, Family and Demography under the President of the Russian Federation, the Commission on Women's Affairs under the Chairman of the Government of the Russian Federation, the Center for Gender Expertise under the Council of the Federation. Not a single concept of the country's development contains a thesis on the development of equal opportunities for men and women".

The discussion on the draft Federal Law No. 284965-3 ended rather sadly. The widespread Stop-Gender campaign "against introducing gender-gay politics in the country" influenced the position of the majority of deputies of the State Duma, and consideration of this document was again postponed. The conservative public was able to compromise the very term "gender" in the eyes of public opinion - effectively using the technology of framing - a method that allows you to influence the perception of information by the audience [7]. Abusive labels were put on supporters of the law on gender equality - gender gay politics, sodomites, sexual perverts, etc. The main postulate is that gender equality contradicts the historical and cultural traditions of Russian society.

As noted above, the government nevertheless adopted a document on improving the status of women, which never used the word gender equality. Russia has quite formally complied with international law in the field of women's rights by adopting a rather onesided and vague Strategy of Action for Women. However, the effectiveness of the implementation of this Strategy can be judged by the data of the annual report Global Gender Gap 2018. Russia from 52nd place in 2013 dropped in the ranking of gender equality to 75, leaving behind many countries of the former USSR (see Table 1). 
Table 1. Intermediate indices of gender inequality in four areas: economics, education, health and politics. Post-Soviet countries, 2018

\begin{tabular}{|c|c||c||c|c||c|c|c|c|}
\hline \multirow{2}{*}{} & \multicolumn{2}{|c||}{ Economy } & \multicolumn{2}{c|}{ Education } & \multicolumn{2}{c|}{ Health } & \multicolumn{2}{c|}{ Politics } \\
\cline { 2 - 9 } & $\begin{array}{c}\text { Index } \\
\text { value }\end{array}$ & $\begin{array}{c}\text { Ranking } \\
\text { place }\end{array}$ & $\begin{array}{c}\text { Index } \\
\text { value }\end{array}$ & $\begin{array}{c}\text { Ranking } \\
\text { place }\end{array}$ & $\begin{array}{c}\text { Index } \\
\text { value }\end{array}$ & $\begin{array}{c}\text { Ranking } \\
\text { place }\end{array}$ & $\begin{array}{c}\text { Index } \\
\text { value }\end{array}$ & $\begin{array}{c}\text { Ranking } \\
\text { place }\end{array}$ \\
\hline Latvia & 0.807 & 10 & 1.000 & 1 & 0.980 & 1 & 0.246 & 42 \\
\hline Lithuania & 0.765 & 21 & 0.997 & 53 & 0.980 & 1 & 0.254 & 41 \\
\hline Belarus & 0.838 & 6 & 0.998 & 49 & 0.979 & 52 & 0.173 & 74 \\
\hline Estonia & 0.729 & 42 & 1.000 & 1 & 0.979 & 42 & 0.228 & 51 \\
\hline Moldova & 0.785 & 18 & 0.993 & 69 & 0.980 & 1 & 0.176 & 72 \\
\hline Kazakhstan & 0.741 & 32 & 1.000 & 30 & 0.979 & 42 & 0.130 & 94 \\
\hline Ukraine & 0.747 & 28 & 1.000 & 26 & 0.978 & 56 & 0.107 & 105 \\
\hline Russia & 0.741 & 31 & 1.000 & 28 & 0.980 & 1 & 0.085 & 123 \\
\hline Kirgizstan & 0.662 & 78 & 0.991 & 79 & 0.980 & 1 & 0.130 & 93 \\
\hline Azerbaijan & 0.716 & 47 & 1.000 & 33 & 0.941 & 146 & 0.063 & 137 \\
\hline Armenia & 0.675 & 73 & 1.000 & 35 & 0.939 & 148 & 0.099 & 115 \\
\hline Georgia & 0.654 & 85 & 0.996 & 60 & 0.967 & 123 & 0.093 & 119 \\
\hline Tajikistan & 0.547 & 126 & 0.940 & 118 & 0.976 & 74 & 0.088 & 121 \\
\hline
\end{tabular}

The index of gender inequality in the political sphere is especially great -123 out of 149 in the GGI rating. Once again, the gender paradox is that 546.3 thousand women and 212.4 thousand men work in government posts of the country and its subjects. There are more women in all branches of government at the level of executive positions: in the legislative, executive, judicial and prosecutor's offices. But at the same time, in the Federation Council, for example, only $17.8 \%$ are women, in the State Duma - 15.9\% [8].

Given that Russia is currently undergoing a period of profound changes in various spheres of public life, this conclusion is quite suitable for the existing Russian reality.

In our society, it is precisely the second tendency that is present - traditionally patriarchal gender perceptions are being strengthened, which are more correlated with the asymmetric model of "special rights of women" [9]. Achieving gender equality in Russian society is impossible without the eradication of patriarchal stereotypes that determine the status of women and men [10].

Obviously, these are not only economic or legal, but also cultural factors, which are all the more effective, which are often taken for granted. Gender stereotypes are a factor in the organization of social relations not only between men and women, but also between other social groups and communities that influence public opinion [6].

\section{Discussion}

Considering the perception of the female role in public discourse, it is necessary to turn to the concept of "gender contract", introduced by the Swedish researcher Yvon Hirdmann and reflecting the ratio of female and male roles accepted in different countries [11]. For example, the Soviet gender contract provided for the deprivatization of the role of mother beyond family relations, when the concept of motherhood ceased to be private and became a "public" project. The dominant symbol of the late Soviet years was the figure of a working mother, a woman who played her traditional role and performed domestic work along with high requirements for professional implementation. After the collapse of the Soviet Union, the state retreated from the social sphere and weakened control. And if in post-perestroika times the male role remained stable-patriarchal - to be a defender, earner 
and breadwinner, then the female gender role began to differentiate significantly: the role of a housewife or a "glamorous" housewife was legitimized, the corresponding market connotations appeared - "kept woman", "business - lady "," socialite "etc.

The importance and value of education and self-development were gradually grafted and rooted. It is also important that the establishment of new forms of production and consumption based on information and communication technologies also provided women with new opportunities in gaining access to information and jobs, choosing educational and continuing education strategies, and contributing to the achievement of higher social and cultural status by women. The socio-demographic trends in the formation of the Russian Internet audience correlate with global trends in the gradual elimination of previously significant symbolic and cultural contradictions. Women got a chance to achieve gender parity and eliminate gender asymmetry due to the expansion of global e-civilization.

By the end of the 2010s, the Russian authorities began to carry out the so-called "conservative turn" - a policy to revive traditional gender roles. Despite the fact that the principle of gender equality is not openly disputed even today, the main contribution of women to the public good is still understood as the birth of children and the responsibility for their upbringing. This is evidenced not only by statements of leading Russian politicians, but also various legislative initiatives. The trend is manifested in new proposals to remove the abortion procedure from the state healthcare system and introduce a number of incentive measures (additional financial support for pregnant women, an increase in the amount of maternal capital).

We can state a very contradictory development of gender relations in Russia, which looks even more dramatic compared to Germany, where back in the late 60s of the XX century. the wives asked their husband's written consent for employment and where today, by law, as a politically correct norm, the ban on the use of the image of a housewife in advertising was adopted. For a very short period of time, the idea of a notorious hierarchy and inequality was leveled in Germany, which did not happen in Russia, which at the beginning of the 20th century was significantly ahead of the German cultural context in the degree of equality enshrined at the level of the Constitution, legislative acts and Conventions signed in the Soviet era.

In a situation of imbalance and awareness of the new phase of inequality, when patriarchal stereotypes, which are widely regarded as the norm, continue to dominate in Russia [12], regarding the division of labor by sex, segregation in the workplace, etc., it is necessary to improve the legal regulation of social status and protection women's rights, taking into account the analysis of Russian and foreign experience. Attention must be paid to addressing key systemic issues that lead to discrimination and inequality, including violence against women and the decline in sexual and reproductive rights.

The feminist revolution has succeeded in promoting egalitarian views and decreasing the influence of gender traditionalism, but has yet to convince a substantial minority that gender equality should extend to both public and private spheres of social life[13]. Authors notes, what in the era of global modernization a revision of gender concepts is possible, leading to a radical change in gender relations and their development towards egalitarianism, but the strengthening of traditional patriarchal ideas that preserve the asymmetry of the positions of gender groups and increase their inequality is equally likely.

\section{Conclusions}

Today the question is ripening of how conservative we really are, and to what extent official international ratings, when it comes to gender equality, really reflect the ideas of Russians about the role of men and women in society. The concept of society's competency 
in gender policy issues is being updated as the basis for effective social interpersonal interaction.

Back in 1995, at the Fourth World Conference on Women in Beijing, the international community adopted the Platform for Action to Improve the Status of Girls and Women. Conference participants recognized that progress and development are impossible if one half of the country's population does not have the same rights as the other. Combating gender discrimination can be a difficult task because it runs counter to deep-rooted local traditions[14].

Modern megatrends form beliefs about the increasing role of women in the global, national and regional space, the expansion of their rights and opportunities for selfrealization and protection of their interests. But even where there is a long historical tradition of achieving equal rights, society continues to live in accordance with deep cultural beliefs that are contrary to global trends. Despite the fact that the Russian Federation, both in the historical [15] and in the present period, has always paid attention to issues of equality and protection of the interests of women, issues related to gender policy remain value-sharing for different groups of the population and elites, as well as identifiable and conflict-generating in the public dialogue.

Thus, we can conclude that the gender policy of the Russian Federation is rather contradictory - on the one hand, formal observance of international norms of gender equality, and on the other - active opposition to the formation of egalitarian ideas about the rights of women and men, the growth of the process of masculinization in society. It is necessary to more actively disseminate gender culture in society, especially among young people, to form a real mechanism for implementing the policy of equal rights for women and men at both the federal and regional levels. A century has passed since Russian women achieved de jure equality. According to the calculations of WEF analysts, full gender equality at the global level will be achieved in 108 years, apparently in Russia as many years will pass to establish de facto equality.

\section{Reference}

1. E. Kochergina, Bulletin of Public Opinion J. 3-4 (127), 151-161 (2018) DOI: 10.24411/2070-5107-2018-00020

2. F. Goldscheider, E. Bernhardt, T. Lappegård, Population and Development Review J. 41 (2), 207-239 (2015) DOI: 10.1111/j.1728-4457.2015.00045.x

3. F.D. Blau, L.M. Kahn, Journal of Economic Literature J. 55 (3), 789-865 (2017). DOI: 10.1257/jel.20160995

4. M.A. Cachina, Woman in Russian Society 3 (84), 110-115, (2017). DOI: 10.21064/WinRS.2017.3.10.

5. R. Bénabou, J. Tirole, Quarterly Journal of Economics J. 126(2), 805-855 (2011) DOI: 10.1093/qje/qjr002

6. S.S. Skorniakova, A.S. Safonova, European Proceedings of Social \& Behavioural Sciences 35, 1129-1135 (2017) http://dx.doi.org/10.15405/epsbs.2018.02.133-16.

7. T. Davids, F. van Driel, F. Parren, Journal of International Development J. 26 (3), 396408, (2014) https://doi.org/10.1002/jid.2945

8. V.A. Sushko, International Research Journal J. 1, 157-159, (2017) DOI: 10.23670/IRJ.2017.55.103

9. M.A. Kashina, L.A. Vasilenko, Woman in Russian Society 2, 17-31 (2019) DOI: 10.21064/WinRS.2019.2.2 
10. A. White, Europe-Asia Studies 57(3), 429-455 (2005), DOI:10.1080/09668130500073449

11. Y. Hirdman, and Y. Andreasen, The gender system, 187-207, (Aarhus University Press, Aarhus, 1991).

12. S.G. Aivazova, Woman in Russian Society 4(85), 3-13 (2017). DOI: 10.21064/WinRS.2017.4.1

13. W.J. Scarborough, R. Sin, B. Risman, Genderand Society 33 (2), 173-200 (2019). DOI: $10.1177 / 0891243218809604$

14. Venera Zakirova, Reproductive Health Matters 22(44), 202-212 (2014), DOI: 10.1016/S0968-8080(14)44806-7

15. Elena V. Kochkina, Russian Social Science Review42(2), 44-59, (2001). DOI: 10.2753/RSS1061-1428420244 